\title{
Nascent island tourism policy development in Greenland: A network perspective
}

\author{
Evangelia Petridou \\ Risk and Crisis Research Center, Mid Sweden University, Sweden \\ evangelia.petridou@miun.se
}

Pär M. Olausson

Risk and Crisis Research Center, Mid Sweden University, Sweden

par.olausson@miun.se

\section{Dimitri loannides \\ European Tourism Research Center, Mid Sweden University, Sweden dimitri.ioannides@miun.se}

\begin{abstract}
Following its achievement of Self-Rule status in 2009 Greenland embarked on a series of measures to diversify its economy with an eye towards eventually gaining full independence from Denmark. Tourism was underlined as a key sector for reaching this goal and, consequently, over the last few years there has been a concerted effort to develop the island as an important polar destination. Significantly, the Greenlandic government created the tourism development policy for 2016-2020, which it views as a key instrument for shaping the sector's future. In this paper, we adopted a policy network approach to determine the relational architecture among various stakeholders from the public and private sectors who are seen as relevant to tourism's development. Inter alia, we examined how these actors were linked to each other while examining what kind of tourism networks existed in Greenland and what obstacles might hinder or foster their formation. A thematic analysis of qualitative data on Atlas.ti reveals that though there exist networks in the Greenlandic tourism sector, they are not policy networks and that the Greenlandic government's approach to developing this tourism policy has been top-down, reflecting a 'government' rather than a 'governance' approach. Barriers to the formation of policy networks included lack of a shared image for the future; lack of trust among actors; lack of time and spatial fragmentation hindering iterative interactions, and lack of institutional enabling of information and knowledge sharing.
\end{abstract}

Keywords: governance, Greenland, islands, networks, policy development, tourism

https://doi.org/10.24043/isj.94 • Received December 2018, accepted August 2019

(C) 2019-Institute of Island Studies, University of Prince Edward Island, Canada. 


\section{Introduction}

Policymakers worldwide regularly promote tourism as a tool for local and regional economic development and diversification (Beaumont \& Dredge, 2010; Dieke, 2000; Kimbu \& Ngoasong, 2013). This is especially true for numerous island territories (both sovereign and dependent territories) many of which have a narrow economic base, often dependent on extractive sectors such as fishing and agriculture and depend heavily on imports of vital resources (Fisher \& Encountre, 1998; Watts, 2000). Especially in the case of newly independent island states, since the early 1960s tourism has often been regarded as a key strategy for strengthening the economy (Baldacchino, 2006a, 2006b, 2015; Baum et al, 2000; Briguglio et al, 1996; Ioannides, 1994; McElroy, 2003; Scheyvens \& Momsen, 2008). Nevertheless, whereas previously it was common for top-down government-led actions to promote tourism's growth, during the past two decades there has been a marked shift in numerous destinations towards governance structures whereby policymaking involves a mix of public and private sector stakeholders (Cornelissen, 2005; Mosedale, 2014). This, according to Dredge (2006, p.269), has led to "increased interest in networks as an organising concept for promoting joint action."

In tourism's case, due to its fragmented nature both as a societal phenomenon but also an economic activity, the importance of relational structures bringing people together formally and/or informally cannot be overestimated. Specifically, membership in networks signifies that actors buy into a shared set of goals, while they provide a framework for understanding the development of business ties among members. Additionally, networked governance is seen as a fruitful way of understanding how public-private partnerships are managed (Dredge, 2006). Networks may be conceptualized as structures that embed local values and meanings, which "over time become regimes of power and knowledge that operate to filter, prioritize and promote particular local tourism policy actions and initiatives" (Beaumont \& Dredge, 2010, p.8). Such contextualized arrangements would be well suited to contribute to a nuanced, bottom-up tourism policy, especially if the tourism policy process is considered from the perspective of the actors involved in it (Stevenson et al, 2008). Meanwhile, the presence of tourism-related networks, especially incorporating a mix of public and private-sector actors, could constitute an effective means of developing an integrated planning process enabling a destination to achieve its sustainability goals (Farmaki, 2015; Moscardo, 2011; Nordin \& Svensson, 2007).

While considerable research has focused on networks in the case of tourism businesses (Eber et al, 2018; Wang, 2008; Novelli et al, 2006; Sanz-Ibánez, 2017), scholarship remains opaque when it comes to tourism policy networks (Tyler \& Dinan, 2001; Wang, 2008; Farmaki, 2015). This is especially the case in matters revolving around the conditions fostering the emergence of networks. In this paper, following on from Stevenson, Airey, and Miller (2008), we have chosen to examine Greenland's tourism policy process from the perspective of the actors involved in, as well as affected by, tourism policy. We follow a policy network approach in order to understand the relational architecture of the actors connected to tourism in Greenland, including the national destination management organization (DMO), the tourism outfitters, as well as the public sector at the national and municipal levels. It is important here to delineate the concept of the policy network, which Kickert, Klijn, and Koppenjan (1997) define as "(more or less) stable patterns of social relationships between 
interdependent actors, which take shape around policy problems and/or policy programmes" (qtd. in Knoke \& Kostiuchenko, 2018, p.92). In other words, there is an intentionality, a common organizing principle characterizing policy networks, which goes beyond individual or group actors simply knowing each other, liking or disliking each other, or interacting for purposes unrelated to a policy problem or a policy program.

Our main research question adopts a connectionist view (Henning et al, 2012). First, we map the policy network that is, the more-or-less stable patterns of social interactions among interdependent actors in the field of tourism policy in Greenland. Based on this mapping, we ask: what are the factors that foster or hinder the formation of policy networks (network antecedents) in tourism policy in Greenland?

Greenland is a meaningful case study, inspired by Farmaki's (2015) argument relating to the importance of recognizing the role of contingency when undertaking network governance studies. Greenland may be regarded as a crucial case (Gerring, 2016) through which we investigate and more fully understand the mechanisms involved in network formation and the interactions among actors when it comes to tourism policymaking and implementation. In this respect, this article contributes to the policy studies scholarship. It is a propitious time to look into these matters in this context given that Greenland has, following the start of its Self-Rule era, embarked on a series of measures-including tourism development - to assert a greater degree of autonomy from Denmark. Indeed, as Bjørst and Ren (2015, p.92) state: “Today, tourism development is perceived as one among only a few viable strategies by which Greenland may gain economic independence from the Danish commonwealth. Hence, tourism's economic role is embedded (in discourse) in the ongoing nation-building process in Greenland." The way the cold water islandness of Greenland influences the potential development, activities, and power differentials among actors is at the core of this article's contribution to island studies. More specifically, we build on Baldacchino (2006a, 2006b) in unpacking how the specificities of Greenland as a cold water island - such as being situated in the geographical and political periphery and demonstrating a limited civilian buy-in as well as a lack of political pluralism - affect the formation of policy networks.

The remainder of the paper is structured as follows: after the theoretical section concerning network theory in policymaking, we introduce the case and justify its relevance. We then outline our data and methods and discuss our findings. We wrap up with some concluding remarks.

\section{Governance and networks}

The term 'governance' is broad. It has been discussed, developed, and debated extensively in the literature (Peters, 2000; Pierre, 1998, 2000; Pierre \& Peters, 2000). At the heart of any attempt to understand governance lie the dynamics between state and society and how the government's role in pursuing collective interests has adapted in a society characterized by shifts in late capitalism. These include globalization, consumerism, the fragmentation of authority and the state and the commodification of knowledge (Pierre \& Peters, 2000; Simrell-King, 2005). A shift from 'government' to 'governance' (Montin \& Hedlund, 2009) suggests that the public sector no longer has a monopoly on, or the resources for, policymaking, and though it remains a central actor, it is not the only one (Vas \& Ranchod, 2019). Governance, including aspects of networked governance, have been considered 
specifically in island studies scholarship, both from theoretical and empirical perspectives with diverse case studies (e.g. Polman et al, 2016; González-Morales et al, 2016; Grydehøj, 2016a, 2016b; Grydehøj \& Nurdin, 2016). A nuanced thinking of governance is multi-dimensional and includes notions of power, decision-making and accountability from an actor-centric standpoint: "governance determines who has power, who makes decisions, how other players make their voice heard and how account is rendered" (Institute on Governance [IOG], 2018). Further, we concur with Beaumont and Dredge (2010), who follow Edwards' (qtd. in Beaumont \& Dredge, 2010, p.8) definition of governance as "all forms of organizational relationships." The focus of relationships when it comes to governance arrangements is operationalized in the concept of networks.

Networks are analytical constructions, heuristics, helping us to understand the multiplicity of interdependencies among actors. The definition of a network can be fairly open, a structural conceptualization of an unspecified system of interconnected nodes (Borell \& Johansson, 1998; Eilstrup-Sangionvanni, 2018). Nodes can be individuals but also collective actors, such as organizations, groups, communities or countries. In the public policy arena, at least one governmental node is involved (Koliba \& Koppenjan, 2016). The links connecting the nodes involve social relations, such as transactions, or the exchange of material resources, physical or social mobility, but also exchange of non-material resources such as information, formal roles, and services (Koliba \& Koppenjan, 2016; Wasserman \& Faust, 1994). Policy networks are social networks that are formed for the purpose of fostering stable relations articulated in frequent exchanges and coordinated interests among its members for the benefit of collective action (Adam \& Kriesi, 2007; Cohen, Evans, \& Mills, 2012; see also Klijn \& Koopenjan definition in the introduction). Actors in policy networks have their own goals and agendas but collaborate to reach a common goal, since no single entity (public or private) has the resources to achieve this on its own (Loeffer, 2016). The act of 'working together', if enduring, could result in the institutionalization and strengthening of the relationships among the actors, involving a common language and trust (or distrust) (Koliba \& Koppenjan, 2016).

Knoke and Kostiuchenko (2017) report that while some scholars theoretically distinguish between governance networks and policy networks, others do not. Bevir and Richards (2009) posit that governance actors from the public sector and civil society comprise policy networks, while their interactions result in policies. This renders networks loci of coordination and allocation of resources (Knoke \& Kostiuchenko, 2017). More broadly, Klijn et al (2010, p.1064) define governance networks as "public policy making and implementation through a web of relationships between government, business, and civil society actors," and in a global governance context governance networks are a specific way in which collective action is organized (Eilstrup-Sangiovanni, 2018, see also Powell, 1990). In this study, we use the terms 'policy networks' and 'governance networks' interchangeably.

There exist power differentials among actors in networks (Borgatti et al, 2018). Moreover, networked structures may be either self-organizing or mandated by higher levels of governance (Petridou \& Olausson, 2016; Sparf \& Petridou, 2018). However, there is a risk that the mandated arrangement in networks may negatively affect their efficiency (Olausson \& Nyhlén, 2016). Regardless, a networked structure implies that several actors have a seat at the table and that policymaking is not the sole purview of the formal governmental entities. The context in which we observe the networks makes a difference: in pluralistic systems several actors vie for resources in a competitive environment, whereas in corporatist systems 
the actors are fewer, more organized, with a formal seat at the policymaking table (Adam \& Kriesi, 2007; Petridou, 2017). In the subsection that follows, we discuss the specificities of a policy network approach in tourism policy, paying special attention to the island context.

\section{Policy networks and tourism policy}

At any destination, the tourism system's complexity is reflected in the interplay of a variety of actors, both from the public sphere as well as an assortment of private sector and quasigovernmental players (Novelli et al, 2006). Precisely because there is considerable variation between the roles of these agents, not to mention the tasks they perform or the products they produce and market, there is a need for a high degree of cooperation between them in efforts, for example, to engage in effective destination planning and management (Bramwell, 2011) or to promote tourism in a sustainable manner (Farmaki, 2015). Indeed, a network arrangement can be "assumed to bring several benefits to destinations through the promotion of an integrated planning process, inclusive decision-making and increased synergies and thus support the notion of sustainability" (Farmaki, 2015, p.386).

Despite this argument, Farmaki proceeds to identify that the role of stakeholders in Cyprus' Regional Tourism Organizations (RTO), which were specifically set up as a type of network to pursue sustainability, has been ambiguous. She reveals that the large number of players involved in the network hinders cooperation given their sometimes widely divergent perspectives (see also Dredge, 2006). What was particularly problematic in this case was that the national government clearly favored certain stakeholders over others. Particularly, those private sector stakeholders with multiple positions (e.g., also served as mayors) seemed to gain an unfair advantage over others, thus limiting the effectiveness of the overall governance structure. A parallel obstacle to successful governance structures is that it is, more often than not, extremely hard to encourage local businesses to consider the long-term repercussions of certain actions vis-à-vis short-term benefits. This challenge was identified by Novelli, Schmitz, and Spencer (2006) when examining the need for cooperative arrangements in the UK.

The fact that governance structures often reveal broad inequities between various stakeholders is accentuated by the frequent absence of direct community involvement in such arrangements. Moscardo (2011), in a study of emerging, often peripheral African tourist destinations, laments that community residents are very rarely involved in tourism governance arrangements. Instead, these are predominantly dominated by outside agents both from the public and private sectors. She maintains that this situation has much to do with the prevailing attitude of those guiding the tourism development process that the members of the public are ignorant about the sector to begin with and have not had much, if any, experience with it. This becomes a principal reason for their exclusion (see also Sharpley \& Ussi, 2014).

We must also acknowledge how geography affects the tourism industry in different islands, both in cold-water islands and warm-water islands (Baldacchino, 2006a). Baldacchino finds that the number of visitors is considerably higher in warm water islands, but despite the relatively small footprint of tourism in cold-water islands, its potential impact is proportionately higher (Baldacchino, 2006a). Furthermore, in societies that desire to maintain their traditional way of life, tourism can often be seen as a threat, as evidenced in a study of the polar north (Nilsson, 2008). The need for understanding and trust between the tourism industry, the tourists and the local residents is therefore essential in a polar north spatial context 
(Nilsson, 2008, p.107). When it comes to governance practices, specifically in islands, Baldacchino (2006b) has examined how non-sovereign islands promote innovative development strategies, including those targeted toward to tourism as a key economic development sector (see also McElroy, 2003). Baldacchino (2006b, p.859) maintains that such efforts reflect the prevailing notion that "tourism remains a 'safe' policy domain that does not threaten the authority of the center." He believes that on islands, especially smaller ones, social capital is the glue that binds a local community in pursuing a common goal and that this is what leads to "good governance and effective public policy" (Baldacchino, 2005, p.33; see also Karampela, Kavroudakis, \& Kizos, 2017). Especially relevant for this article is the work of Grydehøj (2016b) who explores democratic institutionalism in subnational governments, calls for place-contingent democracies of scale, and notes, inter alia, that Greenland's institutional dependence on Denmark is partly due to a paucity of local politicaladministrative skill. González-Morales et al (2016) focus on public-private partnerships and the role of corporate social responsibility in the modernization of Fuerteventura as a tourist destination, while Polman et al (2016) elaborate on the difficulty of the self-governance of ecosystems services. Grydehøj and Nurdin (2016), partly drawing from network governance theory, conclude that technology maintains and reinforces power imbalances in the fishing community of Karanrang island in Indonesia.

Finally, several papers relevant for this study, have addressed governance in an island context from a network perspective. Cohen, Evans, and Mills (2012); Karampela, Kavroudakis, and Kizos (2017); and Getimis and Demetropoulou (2017) concur that networks are very important for the adaptive governance of coastal ecosystems in the Solomon Islands, agritourism in Lesvos, and regional governance in the Greek islands of the southern Aegean respectively. Karampela, Kavroudakis, and Kizos (2017) advocate an expanded network governance structure that moves beyond business networks and involves governmental actors. These studies identify a set of factors that create barriers to information and knowledge exchange among stakeholders. Ranchod and Vas (2019), writing about a different context, concur. In the following table, we synthesize this set, articulating it not in the negative (as barriers), but in the affirmative-as factors influencing the process of exchange.

Table 1: Barriers or Enablers? Factors influencing knowledge and information exchange in policy networks. Derived from: Cohen, Evans, \& Mills, 2012; Getimis \& Demetropoulou, 2007; Karampela, Kavroudakis, \& Kizos, 2017; Ranchod \& Vas, 2019.

\begin{tabular}{l}
\hline $\begin{array}{l}\text { A common vision shared among stakeholders; openness and transparency; commitment by } \\
\text { members }\end{array}$ \\
\hline $\begin{array}{l}\text { Trust between actors, including actors at different levels of governance and those in the } \\
\text { public, private, and third sectors }\end{array}$ \\
\hline Time for regular communication and interactions \\
\hline Spatial fragmentation; resources for iterative interactions \\
\hline Institutions enabling information sharing \\
\hline Existence of other, established networks that render new ones redundant. \\
\hline
\end{tabular}

Based on the preceding literature and the data collected for this study as outlined later, and to answer our research questions articulated elsewhere in this paper, we do two things: 
first, we map and identify the interactions among stakeholders in an effort to illustrate the tourism policy network in Greenland. It is crucial here to note the threshold that a policy network necessitates - the ties must be stable and iterative and involve exchange of resources, such as information, knowledge, and advice, and the stakeholders must be engaged in purposeful collaboration based on a shared vision for the future of the policy. If these prerequisites are not met, a policy network does not exist. Second, we code our data based on the themes above, seeking to ascertain whether they facilitate or hinder the process of exchange. We elaborate on our data and methods after the presentation of the case in the section that follows.

\section{The case}

Greenland (Kalaallit Nunaat) is situated between North America and Europe, located north of $60^{\circ}$ latitude (see Figure 1). It is the world's largest non-continental island covering almost 2.2 million $\mathrm{km}^{2}$ with an estimated population of only 58,000 , making its population density 0.02 people $/ \mathrm{km}^{2}$ (Statistics Greenland, 2018). The majority of the population lives in the 17 towns or 54 major settlements, mostly along the southwest coast. The largest town and Greenland's capital is Nuuk with a population of 17,591 (Statistics Greenland, 2016). Other key communities include Ilulissat and Sisimiut. Given the absence of an internal road network linking the island's communities, accessibility entirely depends on either sea or air transportation. Currently, scheduled international air connections are only offered from Copenhagen and, on a seasonal basis, from Reykjavik.

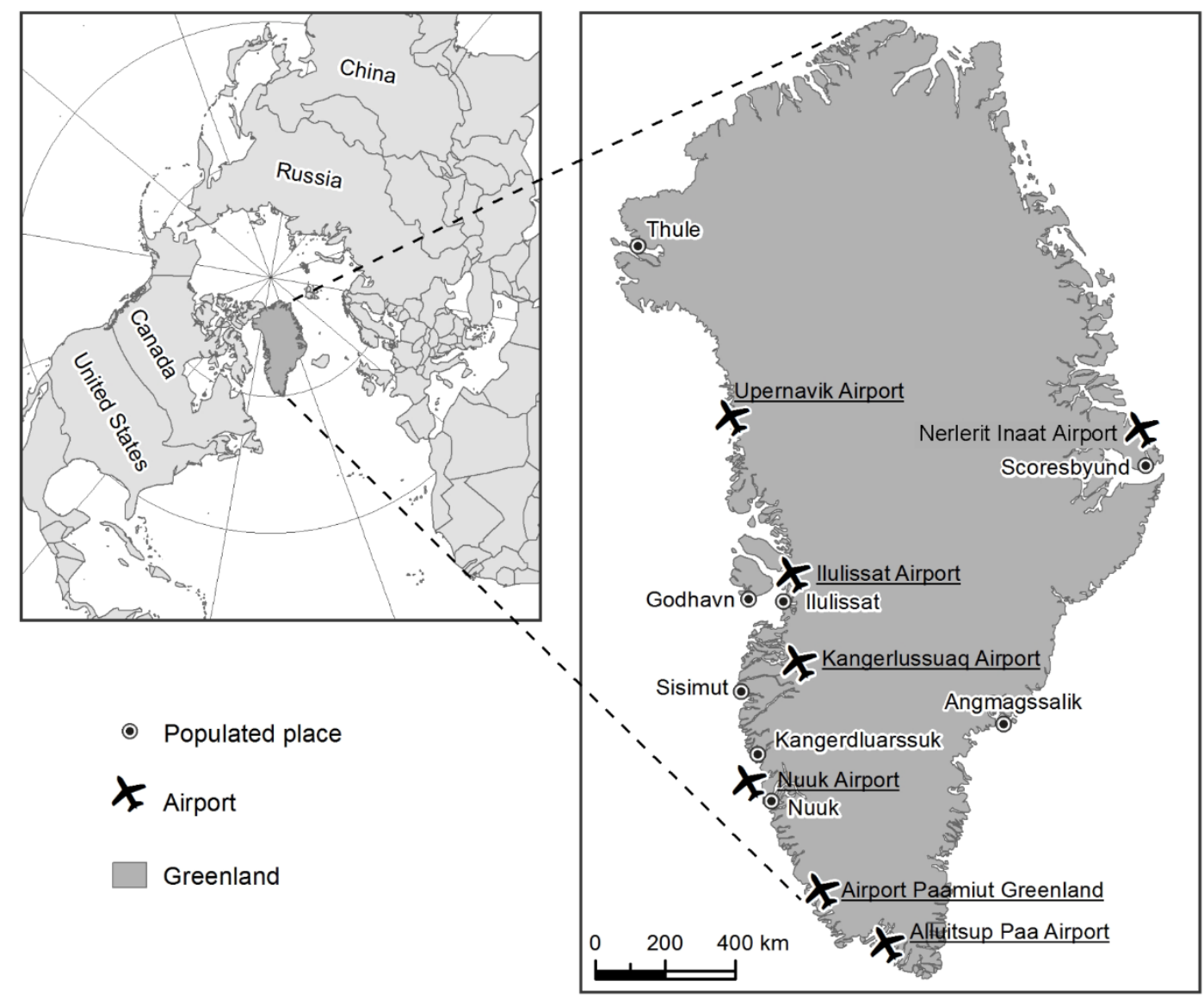

Figure 1: Map of Greenland. Source: (C) Shuo-Sheng 'Derek' Wu. 
Greenland came under Danish control in 1721 and remained a colony until 1954. In a referendum in 1972, more than $70 \%$ of residents of Greenland voted against EEC membership, but since the island at that time was an integral part of Denmark, this result had practically no effect and Greenland joined the Common Market. Increasingly vocal demands for greater domestic autonomy led to Home Rule [Hjemmestyre] rights in 1979. This included control over self-financed areas and limited say over implementation in policy areas subsidized by Denmark (Olausson, 2008; Ackrén, 2016). A follow-up referendum in 1982 led to the island's eventual departure from the EEC in 1985 (Gad, 2014). However, this did not mean that Greenland gained control over its subterranean natural resources. In 2004, the DanishGreenlandic Self-Government Commission started negotiating terms for an expanded selfgovernment of the island, and following a referendum in 2008, the island was granted SelfGovernment status in 2009 (Nuttal, 2008; Mortensen, 2013; Government of Greenland, n.d.; Statsministeriet, n.d.).

Two documents relate to tourism development in Greenland. First and most importantly for the context of this paper, at the central government level, the Ministry of Industry, Labor, Trade and Energy developed a tourism policy for 2016-2020 'Tourism development in Greenland: What does it take?' (Turismeudvikling i Gronland - hvad skal der til?). This calls for reduced taxes and fees assessed on international flights and cruise ships. It focuses heavily on transportation, especially runway extensions in Nuuk, Ilulissat, Tasiilaq, and Qaqortoq. Based on a report by a consultancy firm (Rambøll, 2015) and recommendations of the transport commission (Transportkommissionen, 2011), the main argument is that infrastructural developments in Nuuk, Ilulissat and elsewhere are vital for tourism increase since currently only one international airport, Kangerlussuaq, can receive large passenger aircraft. Normally, passengers flying to Greenland must switch to smaller aircraft when arriving in Kangerlussuaq in order to reach their final destination. This finding contradicts the recommendations of a report completed more than 20 years ago (Scanavia, 1997), which seriously questioned the extension of runways in these places given cost, environmental and safety considerations.

Furthermore, the tourism policy outlines the importance of producing local plans for the development of tourism in various communities, focusing especially on accommodation and the creation of five visitor centers. Finally, it stresses the need for students from Greenland to study abroad. The document advocates that marketing efforts should focus on Iceland, Germany, North America, and Asia. A main objective is to capitalize on the windfall of tourists in Iceland by incorporating side tours from Iceland to Greenland.

Visit Greenland, the national destination management organization (DMO), has produced its 'National Tourism Strategy 2016-2019', which also focuses heavily on transportation issues, although the emphasis is on developing better marketing efforts. (Visit Greenland, 2016). The DMO's overriding goal is a 5\% annual increase in visitor arrivals. Visit Greenland sees the establishment of public-private partnerships as vital for achieving this goal. It has invested heavily in creating a platform for international operators to cooperate with local operators through a Business to Business (B2B) model focusing on adventure tourism.

Overall, both the Government's tourism policy and the DMO's tourism development strategy display a bias towards increasing the number of visitors to Greenland in the coming years. To be sure, the term sustainable tourism is often repeated but, regardless, it is evident that the emphasis in on more arrivals and the way to achieve this is through increasing the number of flights and cruise ship dockings. In reality, both these documents fail to 
contemplate the implications of increasing arrivals especially when the current availability of accommodation capacity is limited and much of the tourism-related infrastructure, including museums and other cultural attractions, is in need of improvement.

Although this is a single case study, we contend it is theoretically and empirically relevant. We expect this island in the age of governance to display some form of networked governance in tourism policymaking and implementation. At the same time, despite the increased self-government that the new Self-Government Act implied, a large part of the Greenland administration as well as major businesses are run by Danes, most of whom are likely to return to Denmark after a few years (Grydehøj, 2016a).

Additionally, Greenland is empirically interesting. In an era when the repercussions of climate change have made headline news (Trusel et al, 2018) many see it as a key "last chance" destination where visitors have the opportunity to observe ice sheets, glaciers, or icebergs before they disappear or catch a rare glimpse of the dwindling numbers wildlife of polar bears (Lemelin et al, 2010). As climate change fundamentally shifts the way peripheral areas (in the extreme north and elsewhere) understand themselves, it is fruitful to tease out how they assess and exploit their shifting circumstances. Two seemingly contrasting narratives comprise the vision of tourism development and the future of Greenland: a 'cold' Greenland, a global symbol for climate change, and a 'hot' Greenland, embracing the melting, on its way towards economic prosperity (Bjørst \& Ren, 2015). Bjørst and Ren (2015) conclude that these are not mutually exclusive images; rather, they are intertwined, reflecting entangled and contested visions of sustainability and industrialization, climate changes, and the political and social contingencies of Greenland.

\section{Data and methods}

Data for our study on Greenland's tourism policy development consisted of desktop and document research; event ethnography; participant observation; a focus group meeting; and stakeholder interviews. The network perspective on Greenland's tourism development investigated in this paper is but one part of this study's broader research scope. Initial desktop research resulted in a pool of interviewees, that is, tourism entrepreneurs and representatives of the destination management organization; a municipality; and the Ministry of Industry, Labor, and Trade. We contacted them via e-mail and subsequently asked them for further contacts, effectively employing snowball sampling. The final pool of interviewees, in addition to the roles mentioned above, included a representative of the UNESCO World Heritage site and a college instructor in the field of tourism and hospitality education.

We carried out 13 semi-structured interviews, 11 of which were conducted face-toface in two separate field research visits to Greenland in May 2016 and September 2017. Two interviews were conducted over Skype. The face-to-face interviews were recorder and transcribed. We took detailed notes during the Skype interviews. Additionally, Ioannides participated in a tour with a tourism entrepreneur during the first visit, and Ioannides and Olausson participated in a different tour during the second visit. The authors interacted with the entrepreneur and the other tour participants. Additionally, Ioannides and Olausson attended a travel show during the 2017 visit. During the same visit, the authors arranged a presentation followed by a focus group meeting at the University of Greenland. The invitation was open to members of the community who were interested in tourism. Nine 
individuals comprised the focus group, including two faculty members, three students (one of whom worked for a tour operator), one psychologist, two employees of a commercial shipping company, and one travel agent. Extensive notes were taken after all these events.

We analyzed the data on Atlas.ti (Friese, 2014). We used a thematic analytic approach for the coding of the material, on the one hand deductive, because it was guided by the tenets of network architecture-nodes and relationships among them, as well as the intentional and purposeful collaboration that is integral to a policy network. On the other hand, our thematic analysis was inductive, because the information emerging from coded material informed our results (Boyatzis, 1998; Callaghan \& Sylverster, 2019; Braun \& Clarke, 2006). The authors discussed the coding during several meetings and the final output is 111 codes in ten groups, not all of which are part of the ensuing discussion. The collaborative coding enriched the analysis through the dialectic process of the inductive analysis (Weston et al, 2001).

\section{Analysis of results and discussion}

Images of the future of tourism policy

Perhaps the most fundamental theme that emerges from our data is the lack of a unified vision for the future of Greenland. This echoes Bjørst and Ren's (2015) analysis of (a 'cold') Greenland as a global symbol for climate change vs. (a 'hot') Greenland on its way to industrialization. The official from the ministry of Industry, Labor, and Trade expressed the dimensions of this cleavage as such:

In Greenland the discussion goes both ways, I think it's more the question when people look from the outside into Greenland. In Greenland it creates huge problems for the traditional hunters in the north [...] For the farmers in the south it's fantastic, because they have a longer growth season so they can harvest more grass for their sheep so it gets cheaper [...] For the mining sector, you know the new, as the ice retreats it gives new land. As the sea ice is getting lesser and thinner it gives new opportunities. Far north we have a zinc project [...] way, way up north. So obviously there are both sides.

In terms of the tourism strategy specifically, the representative continues:

It goes like this, when we make strategies the process is that obviously we have a close cooperation with Visit Greenland, [which] actually has a close connection with all tourism [actors] [...] And then we make a draft and then it goes to a hearing so it's sent out so everyone can comment, and they do, and then we incorporate the comments. It's a small industry, in that sense also a small country so we actually are pretty much close.

This feeling is echoed by the municipal official who is also a member of the local business council that was established in 2012 by the municipality to which Nuuk belongs in collaboration with Greenland's two banks. The council includes employee and employer associations, the country's hunter and fishermen organization, and the Greenland Business Association. The municipal official states: 
So, we have a growth plan for the coming years, and the growth plan should be parallel to the political plan for extending our runway at the Nuuk airport. So, we have all in all, together with the partners in the businesses, a growth plan that accommodates both their local business but also the political wish on having a longer runway in Nuuk. That's the aim [of] our work.

However, Visit Greenland highlights a divergent experience: "They [the ministry] pretty much created this strategy, and then they gave it a hearing. And we could give an internal review of the strategy, which we did. Don't think it made a lot of difference." Meanwhile, the tourism entrepreneurs stated that they were excluded from the national strategy-making experience: "We are not part of making the strategy. And this is why we are not completely aligned" (Tourism Entrepreneur 1). This sentiment of being outside the decision-making process was echoed by the tourism entrepreneurs we interviewed as well as the participants in the focus group meeting. They state that despite the hearing and the process of referral which took place, they feel that the comments they made were not taken into account by the policy makers. Most entrepreneurs do not support extending the runways in Nuuk and Ilulissat, which has been a focus of the governmental strategy on tourism.

More specifically, respondents agree that infrastructure is a key issue for developing tourism in Greenland. However, perspectives differ between the government and the business owners. The governmental tourism strategy foregrounds the extension of several runways and the development or expansion of cruise ship facilities as a means of encouraging Greenland's future tourism development. Conversely, the business owners stress the importance of forward thinking and the implementation of a proper plan for exploiting such expensive infrastructure so that it actually benefits the tourism sector as a whole since currently "the whole strategy just builds on the utopia that if you just build those airports, then tourism is just going to grow by itself' (Tourism Entrepreneur 6). The business owners emphasize two points. First, they see the need to invest in smaller-scale projects such as updating harbors to facilitate boat excursions. Second, they note an uneven geographical but also seasonal distribution of tourists, an issue they posit could partially be solved through better, and ultimately less expensive to use, infrastructure.

This divergence of vision and feelings of exclusion from the formal decision-making process results in dissatisfaction and a lack of buy-in, with which our observations concurred. At the same time, the public sector officials state that they involve the private businesses; it is thus unclear whether these actions are nominal or just not very effective.

\section{Trust between actors}

There is a palpable suspicion and lack of trust from the part of the tourism entrepreneurs towards the national government. Respondents feel that the government apparatus has been entrenched, in power for a long time, and removed from the needs of citizens. We must stress here that these statements are not meant to depict an objective reality; rather, they speak to the attitude of our interviewees towards their government when it comes to tourism policy development. Trust and transparency are fundamental components of social networks in general and policy networks in particular, and without them, the existence of networks becomes untenable. 
Time for regular interactions: spatial fragmentation and resources of iterative interactions

The discussion thus far is a corollary of perhaps the greatest obstacle in the development of tourism in Greenland, namely the island's geography, which makes it hard not only for tourists to move around, but also for various stakeholders-including interested citizens- to meet face-to-face. Additionally, internet access in Greenland (including in most tourist businesses) is limited and expensive (Øgaard, 2016, p.88; Tourism Entrepreneur 7). What is more, often tourism entrepreneurs in Greenland are micro businesses, which leaves little time for engagement with other activities, especially during the tourism season. These factors exacerbate the difficulties of bringing people together to collaborate or even just talk and exchange opinions. Policy networks, as explained elsewhere in this paper, presuppose a pattern of stable interactions among actors

Institutional enabling of information sharing and existence of established networks

Nevertheless, there is evidence of certain forms of collaboration in Greenland. Ren and Chimirri (2017) reflect that, due to the small size of tourism businesses, many of them collaborate. We also found evidence of collaboration among the tourism entrepreneurs, as well as B2B network outreach with tourism outfitters outside Greenland. These networks, however, are not policy networks per se. Rather, they are informal networks, providing the tourism entrepreneurs the opportunity to cooperate or help each other when necessary regarding everyday workflows and customer service.

As mentioned elsewhere in this paper, there is a Nuuk-based business association network. Established, well-functioning networks act as a deterrent to the emergence of new ones, because belonging in a network has high transaction costs for actors-not only in time and financial resources, especially when transportation is expensive, but also in terms of trust. If actors already have an effective communication and resource-exchange channel at their disposal, the incentive to establish another one is low. However, we did not find any evidence in our research that the business association would hinder the emergence of a tourism policy network. The Greenlandic environment could accommodate other collective arrangements as respondents report they wished there were more networks in place. The hearings mentioned elsewhere in this paper are a form of institutionalized information exchange, but this information usually flows one way: from citizens to the government actors and not vice versa.

According to the literature outlined earlier in this paper, we would expect to see some kind of collaboration between the public, private, and third sectors in terms of developing the national tourism strategy, especially given the existence of formalized business associations and interest groups. However, despite the existence of networks for other purposes, the ties among the various actors do not reach the threshold of a policy network, that is, stable or iterative patterns of collaboration for intentional collaboration on policy development.

\section{Conclusions}

In this study, we set out to investigate the development of Greenland's tourism policy from a policy network perspective. Broadly speaking, the national government's tourism strategy is growth oriented and addresses tourism as an extractive industry. What is more, we found interactions among different levels of public sector actors, interactions between public sector actors and the DMO, and interactions between the DMO and tourism entrepreneurs, placing 
the DMO essentially in the middle of these two camps. In network terms, the DMO holds the position of a broker, mediating between two sets of actors. However, we found no evidence of stable patterns of collaborative activities nor any purposeful resource, knowledge and information exchange or iterative interactions between public and private sector actors. Such an absence contravenes the definition of a policy network. In a nutshell, in the government-governance continuum - where 'government' foregrounds the primacy of the governmental apparatus in making policy and 'governance' describes a flat, non-hierarchical arrangement in which governmental actors are part of the policymaking process but do not dominate it (e.g. Montin \& Hedlund, 2009)—Greenland is firmly anchored in the former, with the national government controlling the policymaking process, leaving little room for other stakeholders.

As reflected in the literature from warm water islands (for example, the Aegean islands and the Solomon Islands) as well as public policy literature, we identified barriers to the emergence of policy networks in our qualitative data, including: lack of a shared vision of the future; lack of trust towards the public sector; lack of time for regular interactions; spatial fragmentation; and lack of institutional mechanisms for two-way resource, knowledge, and information exchange. By contrast, existence of established networks did not seem to affect the emergence of a policy network.

The study's limitation centers on the fact that it focuses on a single case: we investigated only one policy sector in one idiosyncratic political context. There are two trajectories that future research may follow with this study as a departure point. First, additional research is needed to further validate our results. Further studies could focus on investigating in depth the institutional setting in Greenland in other policy sectors. Such an analysis could go a long way towards providing a nuanced discussion on the island's institutional realities. Additionally, further research could employ formal social network analysis (SNA) in order to visualize the actors, the types, and strength of ties among them.

Secondly, and more broadly, this study has policy implications for other island and polar areas that seek to capitalize on climate change to increase tourism as a tool of economic development. For example, a study could compare Greenland with the tourism policy in the Faroe Islands, which has also been under Danish rule, and even broaden the spatial scope of a comparative study. The insights of the Greenland case can facilitate our understanding of tourism policy in the making and contribute to policy learning.

\section{Acknowledgments}

The authors would like to thank the anonymous reviewers and Adam Grydehøj for valuable input in earlier versions of this article, as well as cartographer Derek Wu for creating the map of Greenland.

\section{References}

Ackrén, M. (2016). Public consultation processes in Greenland regarding the mining industry. Arctic Review, 7(1), 3-19. https://doi.org/10.17585/arctic.v7.216

Adam, S., \& Kriesi, H. (2007). The network approach. In P. A. Sabatier (ed.), Theories of the policy process (pp. 129-54). Boulder: Westview Press. 
Atterton, J. (2007). The 'strength of weak ties': Social networking by business owners in the Highlands and Islands of Scotland. Sociologia Ruralis, 47(3), 228-245. https://doi.org/10.1111/j.1467-9523.2007.00435.x

Baldacchino, G. (ed.) (2015). Archipelago tourism: Policies and practices. Farnham: Ashgate.

Baldacchino, G. (2006a). Warm versus cold water island tourism. Island Studies Journal, 1(2), 183-200.

Baldacchino, G. (2006b). Innovative development strategies from no-sovereign island jurisdictions? A global review of economic policy and governance practices. World Development, 5, 852-867. https://doi.org/10.1016/j.worlddev.2005.10.004

Baldacchino, G. (2005). The contribution of 'social capital' to economic growth: Lessons from island jurisdictions. The Round Table, 94(1), 31-46. https://doi.org/10.1080/00358530500033075

Baum, T. G., Hagen-Grant, L., Jolliffe, L., Lambert, S., \& Sigurjonsson, B. (2000). Tourism and cold water islands in the North Atlantic. In G. Baldacchino \& D. Milne (eds.). Lessons from the political economy of small islands (pp. 214-229). London: Palgrave Macmillan. https://doi.org/10.1007/978-1-349-62865-0 13

Beaumont, N., \& Dredge, D. (2010). Local tourism governance: A comparison of three network approaches. Journal of Sustainable Tourism, 18(1), 7-28. https://doi.org/10.1080/09669580903215139

Bevir, M., \& Richards, D. (2009). Decentring policy networks: A theoretical agenda. Public Administration, 87(1), 3-14. https://doi.org/10.1111/j.1467-9299.2008.01736.x

Bjørst, L. R., \& Ren, C. (2015). Steaming up or staying cool? Tourism development and Greenlandic futures in the light of climate change. Arctic Anthropology, 52(1), 91-101. https://doi.org/10.3368/aa.52.1.91

Bogason, P., \& Musso, J. A. (2006). The democratic prospects of network governance. The American Review of Public Administration, 36(1), 3-18. https://doi.org/10.1177/0275074005282581

Borell, K., \& Johansson, R. (1996). Samhället som nätverk: Om nätverksanalys och samhällsteori. Lund: Studentlitteratur.

Borgatti, S. P., Everett, M. G., \& Johnson, J. C. (2018). Analyzing social networks (2 ${ }^{\text {nd }}$ ed). Thousand Oaks: Sage

Boyatzis, R. E. (1998). Qualitative information: Thematic analysis and code development. Los Angeles: Sage.

Bramwell, B. (2011). Governance, the state and sustainable tourism: A political economy approach. Journal of Sustainable Tourism, 19(4-5) 459-477. https://doi.org/10.1080/09669582.2011.576765

Braun, V., \& Clarke, V. (2006). Using thematic analysis in psychology. Qualitative Research in Psychology, 3(2), 77-101. https://doi.org/10.1191/1478088706qp063oa

Briguglio, L., Archer, B., Jafari, J., \& Wall, G. (eds.) (1996). Sustainable tourism in islands and small states - Vol 1: Issues and policies. London: Pinter.

Callaghan, T., \& Sylvester, S. (2019). Private citizens as policy entrepreneurs: Evidence from autism mandates and parental political mobilization. Policy Studies Journal. Epub ahead of print. https://doi.org/10.1111/psj.12346

Cornelissen, S. (2005). The global tourism system: Governance, development and lessons from South Africa. Aldershot: Ashgate. 
Dieke, P. U. C. (ed.) (2010). The Political economy of tourism development in Africa. Elmsford: Cognizant Communication Corporation.

Dredge, D. (2006). Policy networks and the local organisation of tourism. Tourism Management, 27(2), 269-280. https://doi.org/10.1016/j.tourman.2004.10.003

Eber, Z. F., Baggio, R., \& Fuchs, M. (2018). Network analysis of a multi destination region: The case of Halland, South Sweden. Information Technology \& Tourism, 20(1-4), 181188. https://doi.org/10.1007/s40558-018-0108-9

Eilstrup-Sangiovanni, M. (2018). Global governance networks. In J. N. Victor, A. H. Montgomery, \& M. Lubell (eds.). The Oxford handbook of political networks (pp. 689-713). Oxford: Oxford University Press. https://doi.org/10.1093/oxfordhb/9780190228217.013.30

Farmaki, A. (2015). Regional network governance and sustainable tourism. Tourism Geographies, 17(3), 385-407. https://doi.org/10.1080/14616688.2015.1036915

Fisher, G., \& Encontre, P. (1998). The economic disadvantages of island developing countries: problems of smallness, remoteness and economies of scale. In G. Baldacchino \& R. Greenwood (eds.). Competing strategies of socio-economic development for small islands. Charlottetown: Institute of Island Studies, University of Prince Edward Island. https://doi.org/10.1002/1099-162x(200010)20:4<356::aid-pad88>3.0.co;2-x

Friese, S. (2014). Qualitative Data Analysis with Atlas.ti (2nd ed.). Thousand Oaks: Sage.

Gad, U. P. (2014). Greenland: A post-Danish sovereign nation state in the making. Cooperation and Conflict, 49(1), 98-118. https://doi.org/10.1177/0010836713514151

Gerring, J. (2008). Case selection for case-study analysis: Qualitative and quantitative techniques. In J. M. Box-Steffensmeier, H. E. Brady, \& D. Collier (eds.). The Oxford handbook of political methodology (pp. 645-684). Oxford: Oxford University Press. https://doi.org/10.1093/oxfordhb/9780199286546.003.0028

González-Morales, O., Álvarez-González, J. A., Sanfiel-Fumero, M. Á., \& Armas-Cruz, Y. (2016). Governance, corporate social responsibility and cooperation in sustainable tourist destinations: The case of the Island of Fuerteventura. Island Studies Journal, 11(2), 561-584. https://doi.org/10.4018/978-1-4666-9902-1.ch020

Government of Greenland (2016). Turismeudvikling $i$ Gronland Hvad skal der til? Retrieved from http://naalakkersuisut.gl/ /media/Nanoq/Files/Hearings/2015/Turismestrategi/Doc uments/Turismestrategi\%202016-2020\%20FINAL\%20DK.pdf

Grydehøj, A. (2016a). Navigating the binaries of island independence and dependence in Greenland: Decolonisation, political culture, and strategic services. Political Geography, 55, 102-112. https://doi.org/10.1016/j.polgeo.2016.09.001

Grydehøj, A. (2016b). Toward subnational democracies of scale: Tensions between democratic legitimacy, legality, and effective governance. Geopolitics, 21(1), 22-42. https://doi.org/10.1080/14650045.2015.1114918

Grydehøj, A., \& Nurdin, N. (2016). Politics of technology in the informal governance of destructive fishing in Spermonde, Indonesia. GeoJournal, 81(2), 281-292. https://doi.org/10.1007/s10708-014-9619-x

Hennig, M., Brandes, U., Pfeffer, J., \& Mergel, I. (2012). Studying social networks: A guide to empirical research. Frankfurt: Campus Verlag.

Ioannides, D. (1994). The state, transnationals, and the dynamics of tourism evolution in small island nations. PhD Dissertation. New Brunswick, NJ: Rutgers University. 
Institute on Governance (2018). Defining governance. Retrieved from https://iog.ca/what-isgovernance/

Kimbu, A. N., \& Ngoasong, M. Z. (2013). Centralised decentralisation of tourism development: A network perspective. Annals of Tourism Research, 40, 235-259. https://doi.org/10.1016/j.annals.2012.09.005

Klijn, E. H., Steijn, B., \& Edelenbos, J. (2010). The impact of network management on outcomes in governance networks. Public Administration, 88(4), 1063-1082. https://doi.org/10.1111/j.1467-9299.2010.01826.x

Knoke, D., \& Kostiuchenko, T. (2017). Power structures of policy networks. In J. N. Victor, A. H. Montgomery, \& M. Lubell (eds.). The Oxford handbook of political networks. Oxford: Oxford University Press.

Koliba, C., \& Koppenjan, J. (2016). Managing networks and complex adaptive systems. In T. Bovaird \& E. Loeffler (eds.). Public Management and Governance (3rd ed., pp. 250274). New York: Routledge.

Lemelin, H., Dawson, J., Stewart, E. J., Maher, P., \& Lueck, M. (2010). Last chance tourism: The boom, doom, and gloom of visiting vanishing destinations. Current Issues in Tourism, 13(5), 477-493. https://doi.org/10.1080/13683500903406367

Loeffler, E. (2016). Public governance in a networked society. In T. Bovaird \& E. Loeffler (eds.). Public management and governance (3rd ed., pp. 207-222). New York: Routlledge. https://doi.org/10.4324/9780203884096

McElroy, J. L. (2003). Tourism development in small islands across the world. Geografiska Annaler B, 85(4), 231-242. https://doi.org/10.1111/j.0435-3684.2003.00145.x

Montin, S., \& Hedlund, G. (2009). Governance som interactiv samhällsstyrning-gammalt eller nytt i forskning och politik? In G. Hedlund \& S. Montin (eds.). Governance på svenska (pp. 7-36). Stockholm: Santérus Academic Press.

Mortensen, B. O. G. (2013). The quest for resources: The case of Greenland. Journal of Military and Strategic Studies, 15(2), 93-128.

Moscardo, G. (2011). Exploring social representations of tourism planning: Issues of governance. Journal of Sustainable Tourism, 19(4-5), 423-436. https://doi.org/10.1080/09669582.2011.558625

Mosedale, J. (2014). Political economy of tourism: Regulation theory, institutions, and governance networks. In A. A. Lew, C. M. Hall, \& A. M. Williams (Eds.). The Wiley Blackwell companion to tourism (pp. 55-65). Chichester: Wiley Blackwell. https://doi.org/10.1002/9781118474648.ch4

Nordin, S., \& Svensson, B. (2007). Innovative destination governance: The Swedish ski resort of Åre. International Journal of Entrepreneurship and Innovation, 8(1), 53-66. https://doi.org/10.5367/000000007780007416

Novelli, M., Schmitz, B., \& Spencer, T. (2006). Networks, clusters and innovation in tourism: A UK experience. Tourism Management, 27(6), 1141-1152. https://doi.org/10.1016/j.tourman.2005.11.011

Nuttall, M. (2008). Self-rule in Greenland: Towards the world's first independent Inuit state. Indigenous Affairs, 8(3-4), 64-70.

Nilsson, P. Å. (2008). Tourism in cold water islands: A matter of contract? Experiences from destination development in the polar north. Island Studies Journal, 3(1), 97-112. 
Olausson, P. M. (2008). Autonomy and islands: A global study of the factors that determine island autonomy. Åbo: Åbo Akademis förlag.

Peters, B. G. (2000). Governance and comparative politics. In J. Pierre (ed.). Debating governance: Authority, steering, and democracy (pp. 36-55). Oxford: Oxford University Press. https://doi.org/10.1017/s000305540281036x

Petridou, E. (2017). Political entrepreneurship in Swedish: Towards a (re)theorization of entrepreneurial agency. Doctor of Philosophy Doctoral Dissertation. Mid Sweden University, Östersund. https://doi.org/10.1515/cejpp-2016-0028

Pierre, J. (1998). Public-private partnerships and urban governance: Introduction. In J. Pierre (ed.). Partnerships in urban governance: European and American experience (pp. 1-10). Hampshire: MacMillan. https://doi.org/10.1007/978-1-349-14408-2 1

Pierre, J. (2000). Introduction: understanding governance. In J. Pierre (ed.). Debating governance: Authority, steering, and democracy (pp. 1-10). Oxford: Oxford University Press. https://doi.org/10.1017/s000305540281036x

Pierre, J., \& Peters, B. G. (2000). Governance, politics, and the state. Hampshire: Palgrave MacMillan.

Polman, N., Reinhard, S., van Bets, L. K., \& Kuhlman, T. (2016). Governance of ecosystem services on small islands: Three contrasting cases for St. Eustatius in the Dutch Caribbean. Island Studies Journal, 11(1), 265-284.

Powell, W. (1990). Neither market nor hierarchy: Network forms of organization. Research in Organizational Behaviour, 12, 295-336.

Rambøll. (2015). Turisme udvikling og vaxt gennem andret lufthavnsstruktur. Copenhagen: Rambøll.

Ren, C., \& Chimirri, D. (2017). Turismeudvikling i Gronland: Afdakning og inspiration. Institut for Kultur og Globale Studier, Aalborg Universitet.

Rhodes, R. A. W. (1997) Understanding governance: Policy networks, governance, reflexivity and accountability. Maidenhead: Open University Press.

Sanz-Ibáñez, C. (2017). The evolution of destinations: An evolutionary and relational economic geography approach. Doctoral thesis. Universitat Rovira i Virgili

Scanavia (1997). Rapport vedrørende en neutral sammenlignende analyse af to placeringsmyligheder for en atlantlufthavn i Nuuk, Grønland.

Schout, A., \& Jordan, A. (2005). Coordinated European governance: Self-organizing or centrally steered? Public Administration, 83(1), 201-220. https://doi.org/10.1111/j.0033-3298.2005.00444.x

Sharpley, R, \& Ussi, M. (2014). Tourism and governance in small island developing states (SIDS): The case of Zanzibar. International Journal of Tourism Research, 16, 87-96. https://doi.org/10.1002/jtr.1904

Simrell King, C. (2005). Postmodern public administration: in the shadow of postmodernism. Administrative Theory and Praxis, 27(3) 517-532. https://doi.org/10.1080/10841806.2005.11029504

Scheyvens, R., \& Momsen, J.H. (2008). Tourism and poverty reduction: Issues for small islands. Tourism Geographies, 10(1), 22-41. https://doi.org/10.1080/14616680701825115

Sparf, J., \& Petridou, E. (2018). Collaborations in routine emergency management: Lessons from Sweden. Procedia Engineering, 212, 302-308. https://doi.org/10.1016/j.proeng.2018.01.039

Statistics Greenland (2018). Greenland in figures. Retrieved from http://www.stat.gl/?lang=en 
Statistics Greenland (2016). Statistics Yearbook 2012. Retrieved from http://www.stat.gl/publ/en/SA/201603/pdf/2016\%20statistical\%20yearbook.pdf

Statsministeriet (n.d.). The Greenland Home Rule Act. Act no 577 of 29 November, 1978. Retrieved from http://www.stm.dk/ p 12712.html

Stevenson, N., Airey, D., \& Miller, G. (2008). Tourism policy making: The policymakers' perspectives. Annals of Tourism Research, 35(3), 732-750. https://doi.org/10.1016/j.annals.2008.05.002

Sørensen, E., \& Torfing, J. (2005). The democratic anchorage of governance networks. Scandinavian Political Studies, 28(3), 195-218. https://doi.org/10.1111/j.1467-9477.2005.00129

Transportkommissionen (2011). Transportkommissionen-Beteenkning. Nuuk: Transportkommissionen.

Tregear, A., \& Cooper, S. (2016). Embeddedness, social capital and learning in rural areas: The case of producer cooperatives. Journal of Rural Studies, 44, 101-110. https://doi.org/10.1016/j.jrurstud.2016.01.011

Trusel, L. D., Das, S. B., Osman, M. B., Evans, M. J., Smith, B. E., Fettweis, X., McConnell, J. R., B. P. Y. Noël, \& van den Broeke, M. R. (2018). Nonlinear rise in Greenland runoff in response to post-industrial Arctic warming. Nature, 564(7734), 104-108. https://doi.org/10.1038/s41586-018-0752-4

Tyler, D., \& Dinan, C. (2001). The role of interested groups in England's emerging tourism policy network. Current Issues in Tourism, 4(2-4), 210-252. https://doi.org/10.1080/13683500108667888

Visit Greenland (2016). Tourism strategy 2016-2019. Nuuk: Visit Greenland.

Wang, Y. (2008). Actor perspectives and tourism policy networks in Hangzhou, China. Doctoral dissertation. Sheffield Hallam University.

Wasserman, S., \& Faust, K. (1994). Social network analysis: Methods and applications. Cambridge: Cambridge University Press.

Watts, R. L. (2000). Islands in comparative constitutional perspective. In G. Baldacchino \& D. Milne (eds.). Lessons from the political economy of small islands (pp. 17-39). New York: St. Martin's \& Macmillan. https://doi.org/10.1007/978-1-349-62865-0 2

Weston, C., Gandell, T., Beauchamp, J., McAlpine, L., Wiseman, C., \& Beauchamp, C. (2001). Analyzing interview data: The development and evolution of a coding system. Qualitative Sociology, 24(3), 381-400. https://doi.org/10.1023/a:1010690908200

Øgaard, A. (2016) Educational possibilities in digital communication and infrastructure. In R. Knudsen (ed.). Perspectives on skills: An anthology on informally acquired skills in Greenland. Copenhagen: Greenland Perspective. 